\title{
JIHADISM IN THE ARAB WORLD AFTER 2011: EXPLAINING ITS EXPANSION
}

\author{
Pre-Publication Manuscript to be published in Middle East Policy, Vol. XXIII, No.2 (Fall
}

2016)

\author{
Dr. Brynjar Lia \\ Professor of Middle East Studies \\ Director of Centre for Islamic and Middle East Studies \\ Department of Culture Studies and Oriental Languages \\ Faculty of Humanities, University of Oslo \\ Website: http://www.hf.uio.no/ikos/english/people/aca/brynjarl/index.html
}

One of the most puzzling developments since the watershed event of $9 / 11$ and the onset of the U.S.-led Global War on Terror (GWOT) is the expansion of the jihadi movement in the Arab world. ${ }^{2}$ This has taken place despite serious efforts to prevent it from happening. Massive investments in counterterrorism and counterinsurgency by a U.S.-led international coalition, in cooperation with regional partners, have included the entire spectrum of instruments available in the state toolbox. This extensive and costly campaign notwithstanding, the past 15 years have witnessed a remarkable growth in jihadism as a rebel ideology, as a military guerrilla force and a global terrorist menace. At the time of writing, "the Islamic State" is losing territory in its heartland in Syria and Iraq and in its main regional province in Libya. However, the organization has proved capable of orchestrating an unprecedented campaign of international terrorist violence (outside Iraq and Syria), claiming more than 1,200 lives on five continents between September 2014 and July 2016. ${ }^{3}$ As for the Middle East, a cursory look at key indicators of the strength of jihadism in the region over the past decade similarly confirms an ominous upward trend (see figures).

Over the past few years, it has become brutally apparent that international efforts at combatting jihadism have been a colossal failure. ${ }^{4}$ Instead of sapping the military strength of the global jihadi movement, undermining its ideological appeal, shrinking its recruitment base and drying up its sources of financing, Western and Arab counterterrorism efforts have done exactly the opposite. True, individual measures and tactical campaigns have scored short-term successes, such as the U.S. military surge campaign in Iraq in the late 2000 s and deradicalization programs in Egypt in the 1990s and in Libya and Saudi Arabia in the 2000s. ${ }^{5}$ These intermittent advances have been undone by later developments, however. The goal of reducing jihadism from a global strategic concern to a minor security nuisance has not been achieved. By and large, the counterterrorism campaign has been counterproductive. With the wisdom of hindsight, we cannot escape the conclusion that the combined effect of combating jihadism since 2001 with a primarily "kinetic" strategy — a common euphemism for lethal military force and coercion - has laid the groundwork for a jihadi recruitment bonanza.

Despite repeated calls to shift the global counterterrorism focus towards soft power and greater reliance on law-enforcement methods, military means have remained dominant, though they operate at cross-purposes with efforts countering radicalization and violent extremism. ${ }^{6}$ The post-2011 period has witnessed military interventions - in both small- and large-footprint manifestations - in Afghanistan, Pakistan, Iraq, Syria, Yemen, Somalia, Mali and many other countries. Following the formation of the initially highly secretive Joint Special Operation Command, the U.S. government spearheaded an extensive campaign of targeted killing in dozens of countries around the world, amplified by its drone war, which expanded beyond the AfPak-region to theaters in Africa and the Middle East. ${ }^{7}$ The military 
campaigns were accompanied by the establishment of a global archipelago of clandestine detention facilities, where brutal interrogation techniques bordered on torture.

It is still too early to gauge precisely the long-term effects of the GWOT, but it is manifestly clear that the negative fallout has been considerable, particularly the spread of local versions of the GWOT. In the post-2001 era and especially after the Arab Spring revolutions, a number of Middle Eastern states have made the "war on terrorism" narratives their own, intervening militarily in neighboring countries with the stated purpose of rooting out terrorism. ${ }^{8}$ Examples abound: the ongoing Saudi-led campaign against the Houthi rebels in Yemen, the Egyptian air raids into Libya, Jordan's bombing of ISIS targets in Syria and, not least, Iran's Hezbollah's large-scale deployment of Shiite fighting units in the Syrian civil war.

\section{LOSING HEARTS AND MINDS}

As amply discussed elsewhere, a factor rendering the GWOT-strategy counterproductive is this: military and coercive action in the name of counterterrorism frequently causes civilian casualties and abuses that make it easy for jihadi propagandists to convince their audiences that they are witnessing a war on Islam. While this claim is often made, one needs to dig deeper to examine the actual effect of the GWOT on the "hearts and minds" of the average population in the Middle East. Based on available opinion polls after 2003, it seems abundantly clear that attempts at winning popular support in the battle against al-Qaeda have by and large fallen on deaf ears. Numerous polls in the region show a remarkably high level of support for jihadism (see Figures 1 and 2). Even after the rise of ISIS, the most violent and monstrous face of contemporary jihadism, the ideology still elicits sympathy from millions of people in the region.

Although the aggregate numbers are down from the very high levels of al-Qaeda following the Iraq invasion in $2003,{ }^{9}$ there is still a considerable mass of support for jihadism. In several countries in the region, notably Egypt, Jordan, Palestine and Tunisia, respondents with "a very favorable" or "somewhat favorable" opinion of al-Qaeda represent a double-digit percentage. Sympathy for ISIS is lower; however, even here, between 2 and 10 percent of the respondents in Palestine, Algeria, Mauretania, Sudan, Egypt and Morocco express "very positive" opinions of ISIS. The aggregate in the region as a whole is 3 percent, while the figure is as high as 7 percent when including respondents with a "positive opinion to some extent" of the world's most lethal jihadi organization. From an estimated 355 million inhabitants in the Middle East and North Africa, the polls below suggest that several million people may be very supportive of ISIS and/or al-Qaeda.

Lebanon is a notable exception, with very low support for ISIS and al-Qaeda; this suggests a connection between Sunni Muslim and Arab-nationalist identity and support for jihadism. Given that sympathizers tend to be concentrated in certain city districts and regions, such high figures strongly indicate that the popular basis for jihadism is more than sufficient to allow the insurgents to operate like "a fish in the water," as Maoist guerrilla literature terms it. ${ }^{10}$ The level of popular support is so extensive that the local population in certain areas is willing to go to some length to aid, abet and even glorify "the mujahidin" hiding in their midst. Far from being an isolated terrorist underground or extremist fringe, hated and despised by the surrounding populations, the jihadi movement has managed to gain a foothold among the masses. ${ }^{11}$ 
FIGURE 1. Percentage of respondents expressing either a "very favorable" or "somewhat favorable" opinion of al-Qaeda in selected Arab countries

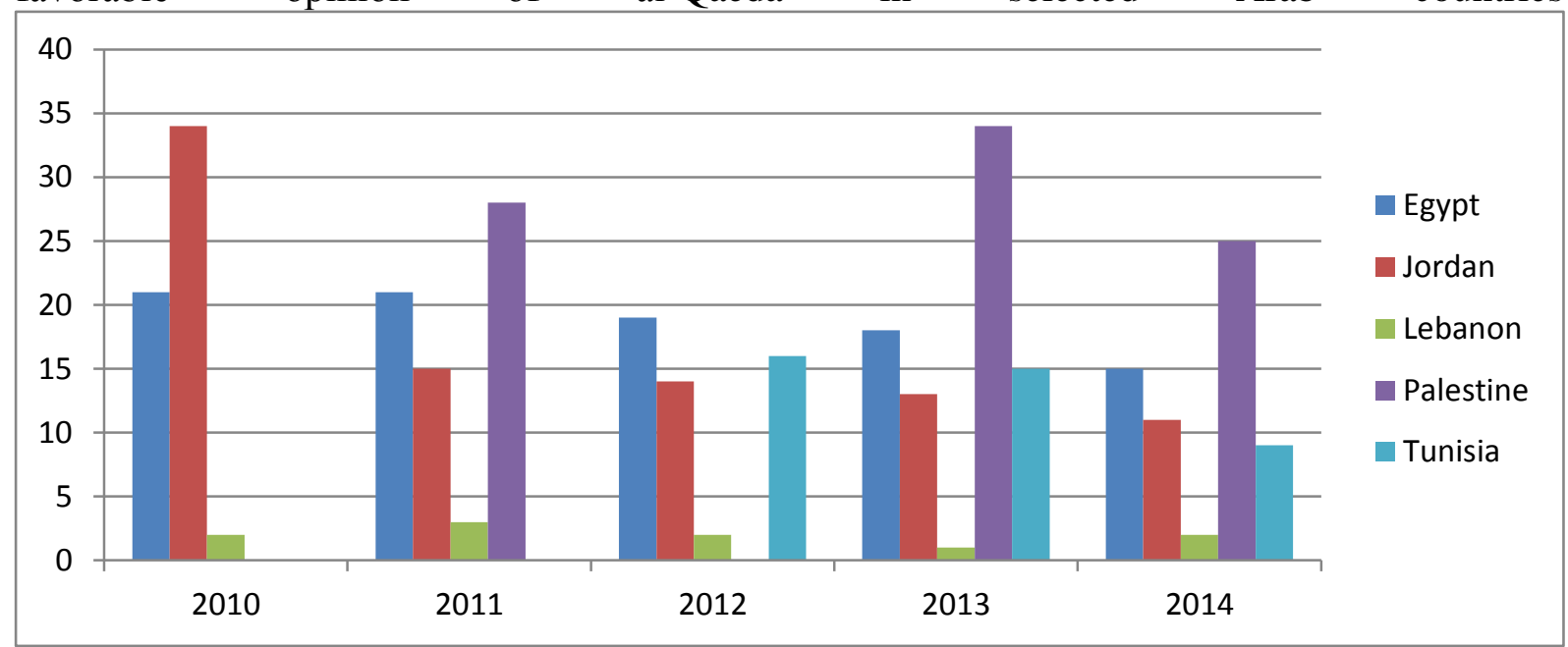

Figures show the aggregate share of respondents choosing "very favorable" and "somewhat favorable" to the question "[p]lease tell me if you have a very favorable, somewhat favorable, somewhat unfavorable or very unfavorable opinion of al Qaeda" (in percentage). Note: data unavailable for Palestine in 2010 and 2012, for Tunisia for 2010 and 2011.

Source: "Concerns about Islamic Extremism on the Rise in the Middle East," Pew Research Center, July 2014, 21.

FIGURE 2. Percentage of respondents expressing a "very positive," "positive to some extent," "neutral," "negative to some extent" or "very negative" opinion of the Islamic State

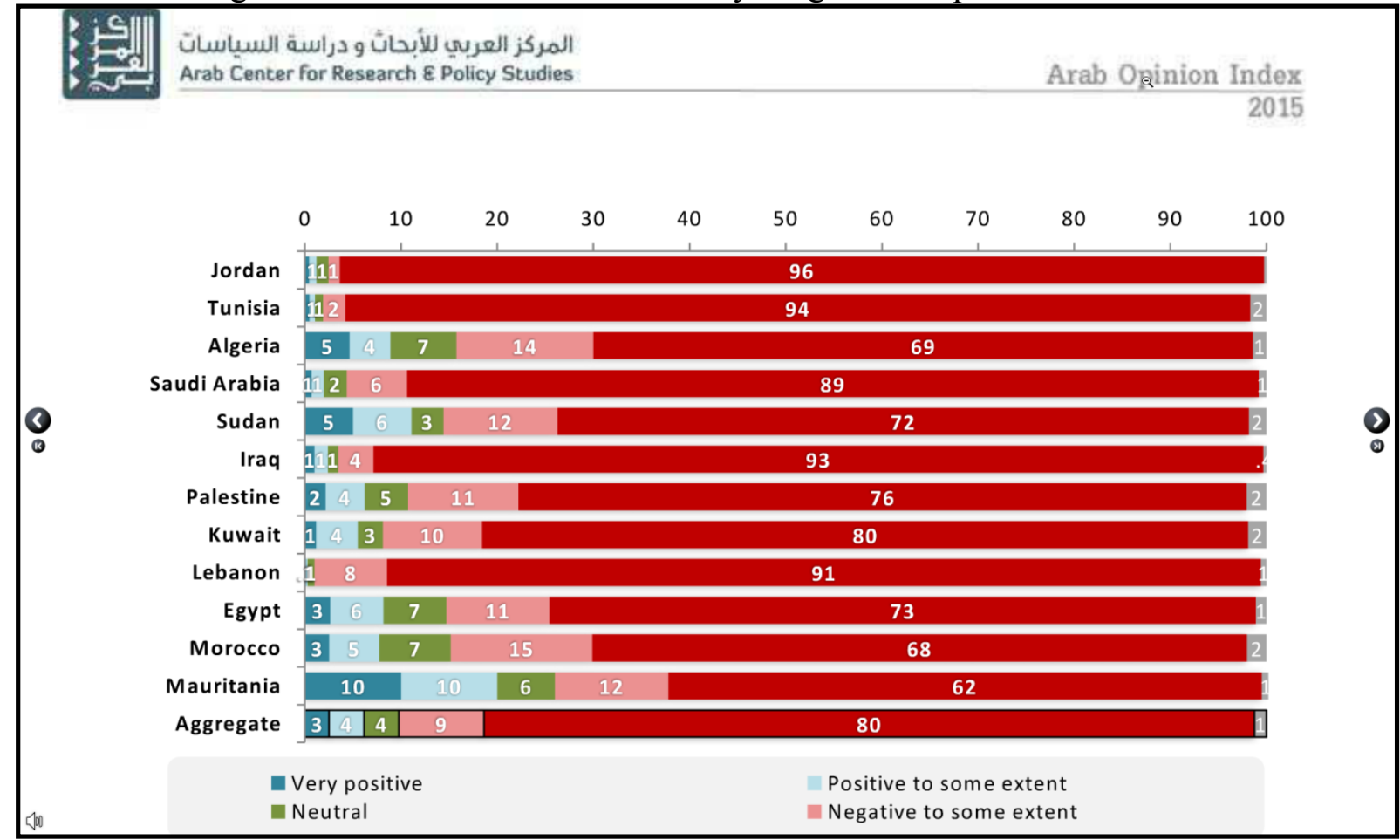

Source: “Arab Opinion Index 2015," Doha: Arab Center for Research \& Policy Studies, 2015, www.dohainstitute.org.

THE EXPANSION AFTER 2011 
The growth and proliferation of jihadi groups were most pronounced in the aftermath of the Arab popular revolts in 2011, the subsequent Saudi-led counterrevolution campaign and the onset of civil wars in Syria, Libya and Yemen. The regional expansion of al-Qaeda affiliates in the Middle East and North Africa long predates the Arab Spring, beginning in Saudi Arabia with the formation of al-Qaeda in the Arabian Peninsula (AQAP), which was active between 2003 and 2006. Other branches were formed in Iraq in 2004 (AQI, redubbed ISI in 2006, morphing later into ISIS and IS), in Algeria in 2006-07 (AQIM, which quickly expanded its operation to most of North Africa) and finally in Yemen (AQAP, active since 2009). ${ }^{12}$

Jihadi rebel groups have a long history in the Middle East, at times representing serious challenges to incumbent regimes. A protracted Islamist rebellion shook Hafiz alAssad's regime in Syria from the late 1970s until 1982. ${ }^{13}$ From the late 1980s until 1997 , Egyptian jihadi militants waged a low-intensity insurgency against the Mubarak regime. ${ }^{14}$ After the Algerian military coup in January 1992, a plethora of Islamist rebel groups took up arms, plunging the country into a devastating civil war that claimed more than 100,000 lives. ${ }^{15}$ By the time of the September 11 attacks in 2001, however, jihadi militancy had retreated as a major security challenge to authoritarian regimes in the Arab world, and militant Islamist groups sought refuge elsewhere. ${ }^{16}$ It was no coincidence, therefore, that the $9 / 11$ attacks originated not in the Middle East, but in Afghanistan, which by the end of the 1990s had become a safe haven for Islamist militants.

During the early post-9/11 period, the U.S.-led war on terror was primarily focused on Afghanistan and Pakistan. The Iraq War of March 2003 proved a turning point, however, paving the way for the formation of the first al-Qaeda branch in the Arab world, in a country with hardly any history of jihadi presence, with the notable exception of small enclaves in the Kurdish-controlled north. ${ }^{17}$ The subsequent creation of al-Qaeda franchises in Yemen, North Africa and Somalia was more a product of a renaming and restructuring of pre-existing Islamist militant groups than the formation of entirely new organizations. ${ }^{18}$ Their appropriation of the al-Qaeda name, narratives and modus operandi, albeit unevenly and not without significant local modifications, was a crucial development. It represented a trend towards the unification of militant Islamism around a global jihad agenda.

Judging from the discourse propagated by official ideologues and random sympathizers alike during the 2000s, the driving force behind this gradual embrace of the AQ agenda and worldview was the new geopolitical reality in the Middle East: the imposition of a U.S.-led military occupation of Arab and Islamic lands. Although couched in a distinctly religious language, the call for resistance against occupation was omnipresent in jihadi discourse. One may argue that it was nationalism - which historically has emerged in many different manifestations in the region, whether local, pan-Arab or pan-Islamist - that drove young people into the hands of jihadism, not religious zeal, bigotry or xenophobia. It was this connection with nationalist sentiments that enabled the jihadi movement to expand from an underground movement to become a socially embedded insurgency.

In the aftermath of the Arab uprisings in 2011, the region has witnessed a sharp, but very uneven, increase in political violence. As can be seen from the tables below, data from the Global Terrorism Database show an increase in most countries, with the notable exception of Morocco and Algeria. The increase is dramatic in countries seriously affected by the Arab Spring revolutions, including Egypt, Libya, Syria, Tunisia and Yemen. The changes after 2011 have been much less pronounced in the conservative monarchies of Jordan, Morocco and Saudi-Arabia, countries that staved off the street protesters with a combination of increases in welfare benefits, salary raises, coercion and promises of political reform. ${ }^{19}$ 
The level of violence in Tunisia, the only Arab country in which the revolutions succeeded in bringing about a transition towards democratic rule, has been contained, despite the existence of a terrorist underground with support bases in neighboring Libya. ${ }^{20}$ Where the revolutions failed to dislodge incumbent regimes, the popular revolts have given way to protracted insurgencies accompanied by extreme counterrevolutionary repression (Egypt) ${ }^{21}$ or descended into full-scale civil wars (Syria, Libya and Yemen). The overall result has been unprecedentedly high levels of violence with a significant spillover effect for neighboring states (Lebanon, Jordan and Saudi Arabia). ${ }^{22}$ Even Iraq, which already had very high levels of violence in the mid- and late 2000s, experienced a post-2011 upsurge, as a byproduct of the Syrian civil war and the rise of ISIS. An exception to the overall upward trend is Algeria, a country that suffered very high levels of jihadi violence in the mid-1990s, followed by a decline in most of the 2000s.

FIGURE 3. Acts of terrorism in the Middle East 1999-2014, based on data harvested from the Global Terrorism Database (GTD)

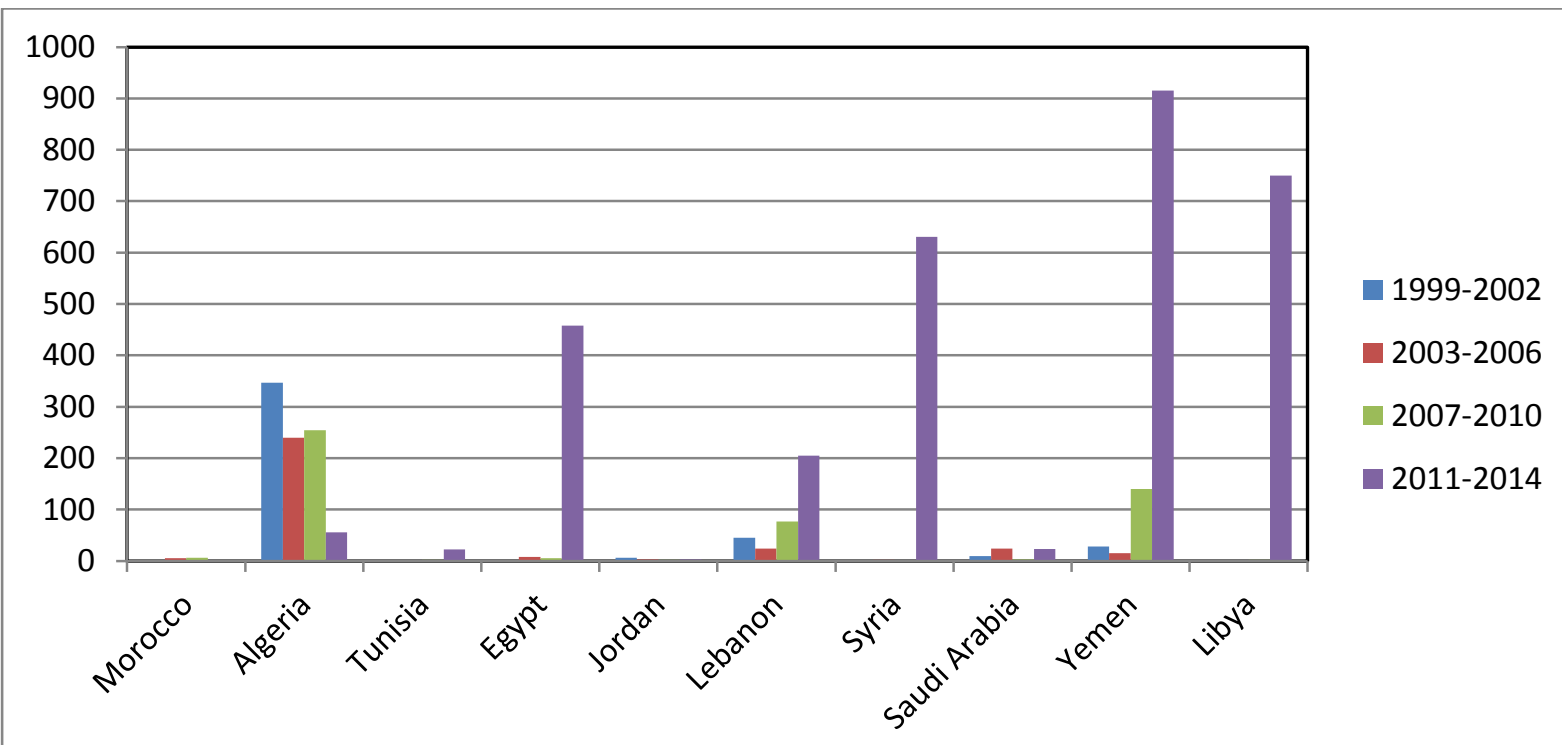

The data is collected from the Global terrorism Database (www.start.umd.edu/gtd), the most acknowledged and comprehensive of existing open access databases on terrorism. The search criteria used for collecting data are as follows: all ambiguous cases have been excluded. Similarly, unsuccessful attacks and plots have been excluded. No attempt has been made to distinguish between jihadi and non-jihadi forms for terrorism. Since jihadi rebel groups are the major perpetrator of terrorist violence outside the civil war zones of Syria, Iraq, Libya, and Yemen, and are also among the most dominant rebel factions in all countries with active insurgencies, the statistics are probably a relatively good mirror image of variations of jihadi violence.

Numerical data do a poor job of conveying the full picture of the transformation of jihadism in the post-2011 era. The quantitative dimension is only a fragment of this metamorphosis. During the Arab Spring revolutions, a much more diverse landscape of jihadism emerged. No longer confined to secretive cells and shadowy networks, jihadi veterans and their sympathisers moved into the open and began operating in a variety of fields, from religious proselytizing (dawa) and charity work to street activism and neighborhood policing as self-appointed sharia enforcers. The weakening of the incumbent regimes in Tunisia, Libya, Egypt and Yemen created space for the jihadis to establish organizations with public offices, engaging in political activism, including sit-ins and public demonstrations. A number of militant Salafist groups emerged, often under the label of Ansar al-Sharia, whose call for armed struggle was tempered by a combination of social activism and a degree of ideological pragmatism regarding when and where armed jihad was obligatory and prioritized. 
This development was most visible in Tunisia and Libya, but the subsequent banning of Ansar al-Sharia in Tunisia led to a contraction of its social activism and a more explicit focus on military action. ${ }^{23}$ In the case of Yemen, Ansar al-Sharia was also linked to the existing al-Qaeda branch and served as its public face. A more diverse landscape of jihadism seemed to offer the possibility of a future politicization and taming of jihadism. This prospect was not based on naïve assumptions. After all, the region had by 2011 already witnessed a series of successful deradicalisation initiatives in which a number of armed Islamist groups, factions and ideologues in Morocco, Algeria, Libya, Egypt, Saudi Arabia, Yemen and Lebanon had been coopted, and in some cases also agreed to revise their ideological programs. $^{24}$

The growing involvement of jihadi groups in non-military activities after the Arab Spring suggested that even al-Qaeda-affiliated groups might be susceptible to a transition to civilian life. In this regard, the formation of front organizations by AQAP, one of al-Qaeda's most important regional branches, was an important development, signaling an ambition to expand from a guerrilla organization with a terrorist underground network to a political player. AQAP's formation of Ansar al-Sharia and its growing interaction with society at a local level in southern Yemen was not an isolated development. In fact, the post-2011 era witnessed the gradual transformation of many jihadi movements in the region from terrorist underground groups to "socially embedded insurgent groups" for whom popular support was actively sought and enlisted. ${ }^{25}$ The courting of a popular mass base was nothing new in jihadi ideological discourse. ${ }^{26}$

What was new, however, were the opportunities to practice jihadism as territorial actors and move beyond the monotonous calls for armed struggle alone. Hence, the post-Arab Spring jihadi generation moved to form "emirates" or proto-states on an unprecedented scale. In the five-year period between 2011 and 2016, jihadis created more territorial proto-states than they had done over the more than 20 years since al-Qaeda's foundation in $1988 .^{27}$ This development is part of the jihadi movement's expansion into the civilian realm and its transformation, alluded to above, from a terrorist underground to a socially embedded insurgency. This offers new opportunities for local jihadi groups to market themselves to local and global audiences. By controlling territory and posing as rulers, jihadi rebels from the small "Emirate of Zinjibar" in Yemen to ISIS-controlled Raqqa and Mosul make efforts at "out-governing" the incumbent regime, not simply demonstrating diligence in imposing their extremist interpretations of sharia law and fighting manifestations of polytheism and unbelief. They also promote themselves in mundane fields by enforcing public order, fighting crime, providing public services and showing off their non-corrupt bureaucratic style of governance.

The harsh reality of ISIS rule has been amply described in numerous eyewitness accounts and should not be doubted. Still, in a civil-war zone, any organization that can provide a minimum of safety from government attacks and the killing sprees of ethnosectarian militias will often gain some conditional support from the local population. ${ }^{28}$ In addition, jihadi rebel groups often rely heavily on external support networks that funnel funds and foreign fighters to the war zone, with ISIS being the most successful jihadi recruiter of volunteer fighters from outside the conflict area. By virtue of its success in conquering wide territories in Syria and Iraq and claiming the Caliphate for itself, ISIS has marketed itself to the global jihadi diaspora not only as the most blessed jihadi front, but also as a utopia, a virtuous Islamic state that fulfills long-awaited apocalyptic visions of Islam's final battles at the gates of Jerusalem. Drawing upon these forebodings of the end of times and its undeniable military prowess on the battlefield, ISIS has been more successful than any other jihadi insurgent groups in magnetizing sympathizers worldwide. Over the span of only a few years, ISIS has managed to persuade tens of thousands of foreign volunteers to undertake "the 
obligatory hijra" (emigration) to "live in the shadow of the Caliphate" and fight with the ISIS mujahidin. ${ }^{29}$ This success is even more remarkable given the high casualty rate among foreign volunteers, who often are deployed as cannon fodder and suicide bombers.

TABLE 1. Proliferation of Jihadi Proto-States in the Arab World after 2011

\begin{tabular}{|c|c|c|c|c|c|}
\hline Name & Country/District & $\begin{array}{l}\text { Time } \\
\text { Frame }\end{array}$ & $\begin{array}{l}\text { Territorial } \\
\text { Control }\end{array}$ & $\begin{array}{l}\text { Civilian } \\
\text { Institutions }\end{array}$ & $\begin{array}{l}\text { Foreign } \\
\text { Fighters }\end{array}$ \\
\hline $\begin{array}{ll}\text { AQAP } & - \\
\text { Ansar } & \text { al- } \\
\text { Shari'ah } & \end{array}$ & $\begin{array}{l}\text { Southern } \\
\text { Yemen/Abyan } \\
\text { Province } \\
\text { (Zinjibar, Jaar, } \\
\text { Shuqrah, etc.) }\end{array}$ & $2011-2012$ & Yes & Yes & $\begin{array}{l}\text { Yes, small } \\
\text { numbers }\end{array}$ \\
\hline $\begin{array}{ll}\text { AQIM } & - \\
\text { Ansar al- } \\
\text { Dine, } \\
\text { MUJAO }\end{array}$ & $\begin{array}{l}\text { Northern } \\
\text { Mali/Timbuktu, } \\
\text { Kidal, Gao, etc. }\end{array}$ & $\begin{array}{l}\text { March } \\
\text { 2012-2013 }\end{array}$ & Yes & Yes & $\begin{array}{l}\text { Yes, small } \\
\text { number }\end{array}$ \\
\hline $\begin{array}{l}\text { Jabhat al- } \\
\text { Nusra }\end{array}$ & $\begin{array}{l}\text { Syria, mostly in } \\
\text { North-Western } \\
\text { (Idlib) since } 2015\end{array}$ & 2012/2015- & Yes & Yes & $\begin{array}{l}\text { Yes, but far } \\
\text { fewer than } \\
\text { ISIS/IS }\end{array}$ \\
\hline $\begin{array}{l}\text { Islamic } \\
\text { State of Iraq } \\
\text { and Sham } \\
\text { /The Islamic } \\
\text { State }\end{array}$ & $\begin{array}{l}\text { Large parts of } \\
\text { northern Syria } \\
\text { and western Iraq }\end{array}$ & 2013- & Yes & Yes & $\begin{array}{l}\text { Yes, } \\
\text { unprecedented } \\
\text { high numbers }\end{array}$ \\
\hline $\begin{array}{l}\text { MSSI, } \\
\text { Ansar al- } \\
\text { Shariah } \\
\text { Libya and } \\
\text { IS } \\
\text { Provinces }\end{array}$ & $\begin{array}{l}\text { Libya, Benghazi } \\
\text { districts, Derna } \\
(2014) \text { and in } \\
\text { Sirte (since mid- } \\
2015)\end{array}$ & $2014-$ & Yes & Yes & $\begin{array}{l}\text { Yes, very } \\
\text { high } \\
\text { percentage, } \\
\text { mostly from } \\
\text { the African } \\
\text { continent }\end{array}$ \\
\hline $\begin{array}{l}\text { Bayt Ansar } \\
\text { al-Baqdis } \\
\text { - Islamic } \\
\text { State's Sinai } \\
\text { Province }\end{array}$ & Egypt/Sinai & 2011- & No & unknown & $\begin{array}{l}\text { Yes, small } \\
\text { numbers }\end{array}$ \\
\hline $\begin{array}{l}\text { AQAP - } \\
\text { Ansar al- } \\
\text { Shari'ah, } \\
\text { Sons of } \\
\text { Hadramawt } \\
\end{array}$ & $\begin{array}{l}\text { South Yemen, } \\
\text { including } \\
\text { Mukallah, } \\
\text { Zinjibar, Jaar }\end{array}$ & $2015-$ & Yes & $\begin{array}{l}\text { Yes, } \\
\text { Civilian } \\
\text { Council } \\
\text { appointed }\end{array}$ & $\begin{array}{l}\text { Yes, small } \\
\text { number }\end{array}$ \\
\hline
\end{tabular}

\section{UNDERLYING CAUSES}

The debate over the remarkable expansion of jihadism in the Arab world after 2011 has centered on a range of factors. As a comprehensive discussion of these debates is beyond the scope of this study, it suffices here to survey a few of the most common explanations. The U.S. premature military withdrawal from Iraq on the eve of the Arab Spring, with Prime Minister Nouri al-Maliki exacerbating the Iraqi government's sectarian policies and alienating Sunni constituencies, are frequently seen as key factors behind the regeneration of Iraq's jihadi movement after its crushing military defeats in the late 2000s. The nearly simultaneous 
outbreak of civil war in Syria, causing the regime to gradually withdraw forces and relinquish control over northeastern Syria, paved the way for the establishment of a Syrian sanctuary for what was then a mostly Iraqi-dominated jihadi movement.

\section{The Collapse of Arab States}

More generally, the weakening or collapse of state authority following the Arab Spring revolutions inadvertently facilitated the growth of jihadi groups, not only in Syria, but also in North Africa and Yemen. In the Maghreb region, the collapse of the Qadhafi regime led to the looting of the government's huge arms depots. The tragic fallout of this massive "privatization" of conventional weapons throughout the region was a dramatic upsurge in jihadi insurgent activities, manifestly demonstrated at In Amenas in Algeria, where jihadis seized a well-protected oil facility and conquered huge swathes of territories in northern Mali in 2012. In Yemen, embattled government forces similarly relinquished control over large parts of southern Yemen, allowing AQAP and its supporters to consolidate and reorganize their forces. The descent of Yemen into a civil war in which deposed dictator Ali Abdullah Salih joined forces with the Houthi rebels against the new Saudi-supported regime created a situation in which jihadi insurgents avoided taking sides. They focused instead on slowly rebuilding their territorial bases in the south and winning a degree of local legitimacy through alliances with tribal groups and local civilian elites.

In Libya, a confusingly complex civil war ensued in which the two dominant actors, the Dignity alliance in the east, led by General Heftar, and the Dawn coalition, based in Tripoli and Misrata, spent far more energy fighting one another than confronting the emerging threat of ISIS-aligned outfits in Benghazi, Derna and Sirte. Similarly, in Syria, the Assad regime has consistently focused its military resources on the revolutionary opposition forces, not ISIS or the Kurdish enclaves in the northeast, considering the former to be its most dangerous foe. Hence, jihadi expansion in Syria was facilitated by what looked like a de facto Assad-ISIS alliance for much of the early phases of the civil war.

\section{Ambiguity about the U.S. Role}

A key factor underlying the rebirth of jihadism in the region was the new ambiguity surrounding the U.S. role in the Middle East under President Barack Obama. Especially in the Gulf monarchies, the ruling elite took notice of the ease with which the United States had acquiesced in and even applauded the fall of Hosni Mubarak, who, after all, had been a staunch U.S. ally for decades and recipient of annual multi-billion-dollar aid packages since the 1970s. The nuclear deal with Iran similarly aroused Arab suspicion that Washington was becoming lukewarm to its Gulf Arab allies. U.S. Middle East policies had traditionally been based on three main tenets: Israel's security, access to oil and combating terrorism. ${ }^{30}$ The Arab uprisings and the U.S. response raised the uncomfortable specter of regime change, prompting Arab regimes to more proactively remake the region without U.S. guidance. As a result, a new forward-leaning foreign policy ensued, spearheaded by the Saudi monarchy and the UAE. ${ }^{31}$ Two main policy agendas were paramount: the eradication of mainstream Islamism, in general, and the Muslim Brotherhood movement, in particular, as a legitimate political actor in the region and the rallying of Arab opinion behind an aggressive reassertion of Sunni Arab hegemony against the Iranian Shiite menace. 
In this new game of counterrevolution and sectarian mobilization, combating jihadism was not the main priority, despite repeated official protestations about the necessity to wage war on ISIS and al-Qaeda. In fact, by seeking to outlaw the Muslim Brotherhood in the region and by generously funding the new military junta in Egypt from 2013 onwards, the Saudi kingdom and its allies helped bring about the marginalization of the most potent political Islamist alternative to the jihadi movement. In their counterrevolutionary drive against the parliamentary Islamist alternative, the Saudi monarchy and its UAE ally have generously funded the most repressive regime in Egypt in modern times. The effect has been as predicted. ${ }^{32}$ With all political channels closed, thousands of Islamist demonstrators killed and tens of thousands of political prisoners, the ranks of Egyptian jihadi groups swelled with defectors from nonviolent Islamist groups. ${ }^{33}$ Egypt under Sisi's dictatorship faces the most serious jihadi insurgency in post-independence Egypt, greatly surpassing the level of violence during the simmering conflict of the early 1990s. ${ }^{34}$

\section{The Resilience of Transnational Insurgencies}

Another and perhaps more fundamental cause for the remarkable resilience of militant jihadism in the region is its transnational nature. Unlike ethno-nationalist revolts or revolutionary struggles against national authorities, jihadis are not ideologically bound to fight in only one country or against one specific national regime. Al-Qaeda's armed struggle ("global jihad") is pan-Islamist, aimed at the liberation of all Islamic lands, against a coalition of Western countries allied with Arab and Muslim client states. The entire world is a legitimate area of jihadi operations, and over the past 25 years, militant groups sharing alQaeda's ideology have fought in insurgencies from Asia and the Middle East to the Maghreb, the Sahel and East Africa. Hence, on an ideological level, what would have been a crushing military defeat for an ethno-nationalist rebel group is simply a limited tactical setback for the jihadis. This lack of critical geographical "points of gravity" ensures the long-term survival of the global movement despite repeated military defeats and the destruction of local groups.

True, many rebel groups falling under the jihadism label have strong local roots and are manned almost exclusively by local recruits; the local character of rebels claiming to be global jihadis should not be underestimated. ${ }^{35}$ Still, jihadi insurgents, as opposed to local Muslim rebels, interact with a huge network of like-minded groups, operating under al-Qaeda (or ISIS) leadership and supported by a geographically scattered network of dedicated sympathizers around the globe. Over the past decades, this constituency has strengthened its capacity to mobilize funds, operate online propaganda channels and recruit and dispatch foreign fighters. The meteoric rise in the number of foreign fighters entering ISIS battlefields in Syria and Iraq over the past few years is a case in point. Tens of thousands of volunteer combatants have been recruited from dozens of countries around the world, a sobering reminder of the jihadi movement's capacity for military mobilization to its priority fronts. In sum, even though many jihadi groups are still predominantly locally staffed - ISIS in Syria, Iraq and Libya being important exceptions - their interconnectedness to this global resource bank is a vital asset endowing jihadi rebel groups with a unique resilience.

Another explanation for the endurance gained from being a transnational insurgency is human-resource capital. Resilient jihadi groups usually benefit from a core of veterans who have fought on various war fronts over the past decades, some even having participated in the Afghan war of liberation in the 1980s. This accumulated guerrilla expertise is shared among jihadi groups, documented and passed on via a huge and growing online library of memoirs, handbooks, audio-tape lectures and video material. Furthermore, the actual practicing of 
guerrilla warfare in various conflict theaters over a protracted period also serves as a Darwinian process of selecting out very capable combat veterans. The case of the Iraqi front is illustrative. Having gained their first major foothold in the region in post-invasion Iraq, jihadi rebels faced a formidable military adversary on the battlefield. By fighting a protracted insurgency campaign against U.S. combat forces, AQI, the precursor to ISIS, suffered tremendous losses and defections in the mid- and late 2000s, including top leaders. A hard core of Iraq-based jihadis nevertheless survived and managed to reorganize their forces into a coherent organization by the end of the decade. When fighting under the new ISIS flag, the organization proved its military prowess by scoring remarkable victories on the battlefield in 2013-15.

\section{Jihadi War Reporting}

In order to more fully illustrate the transnational character of the contemporary jihadi movement, this study presents new empirical evidence based on its war reporting. Good places to explore the prioritization of jihadi ideological and politico-military issues are the jihadi web forums. They were the primary ideological arenas, meeting places, and communication/propaganda channels for jihadis from the early 2000s until social-media platforms, Twitter in particular, began eroding their position in 2012-13. ${ }^{36}$

An analysis of communiqués posted on top-tier jihadi websites between 2005 and 2013 reveals a pattern strikingly similar to that of global solidarity movements, in which the focus of the activists' struggle changes over time from one region to another, and good news from one front makes up for setbacks from another. Afghanistan and Iraq remained the preeminent focus of the jihadi movement until the Arab Spring in 2011, with Somalia figuring as the third-most-reported jihadi frontline during the same period. Not coincidentally, all three countries experienced protracted periods of full military occupation, either by a U.S.-led coalition or by forces closely allied with the United States. ${ }^{37}$ The explicit focus of jihadi war reporting on insurgent activities in Muslim territories under occupation underscores again how large the theme of resistance to foreign rule looms in the movement's ideology.

Reports from other areas of jihadi insurgent activity represent only a small fraction of the communiqués from Iraq, Afghanistan and Somalia. Still, jihadi war reporting from the Maghreb, Chechnya and the Arabian Peninsula remain present throughout the entire period, reinforcing the image of a global and truly multifront insurgency. The absence of a single dominant front is also a notable feature, with the most active jihadi front alternating among Iraq (2005-07, 2011), Afghanistan (2008-10), Somalia (2012) and Syria (2013). It underscores the dynamic nature of this transnational campaign. A certain Arab ethnocentricity is perhaps discernible towards the end of the period, when war reporting from the Taliban insurgency in Afghanistan disappears. ${ }^{38}$ Instead, the statistics become increasingly dominated by the new insurgent groups in Syria. The continued posting of large numbers of Shabaab communiqués in 2012 and 2013, shows, however, that jihadi web-forum administrators continued taking a keen interest in al-Qaeda's new branch organization in the Horn of Africa, even in the midst of dramatic Arab Spring events.

\section{Towards a Grand Coalition}

The ideological basis for a transnational jihadi insurgency, as indicated by the statistical data above, is further reinforced by organizational developments throughout the 
2000s towards a gradual coalescing of local and regional insurgent groups under the al-Qaida umbrella. True, there are many examples of rivalry between jihadi groups, but the idea that this intra-jihadi competition reduces the movement to an empty shell and that there is no jihadi movement is an overstatement. ${ }^{39}$ Examples of cooperation and mergers abound: the Egyptian Islamic Jihad's merger with al-Qaeda in 2001; the absorption of the Tawhid walJihad Group (Zarqawi's outfit) into al-Qaeda in 2004; the Algerian GSPC's conversion to AQIM (Al-Qaeda in the Islamic Maghreb) and its transformation into a regional insurgency in 2006-07; the coalescing of Yemeni and Saudi jihadi militants into AQAP in 2009; alShabaab's formal entry into al-Qaeda in 2012; and finally, the Nusra Front, one of the strongest rebel factions in Syria, confirming its status as al-Qaeda's Syria branch. ${ }^{40}$ A similar trend under the ISIS umbrella has been apparent in the post-2011 period: the absorption into ISIS of the Ansar al-Islam organization, one of the most lethal rebel groups in Iraq throughout the 2000s; the transformation of the Egypt-based Ansar Bayt al-Maqdis group into an ISIS branch ("The Sinai Province") in 2014; and the numerous other pledges of allegiance to ISIS leader "Caliph Ibrahim" by significant insurgent groups like Boko Haram, based in northern Nigeria, and the Islamic Movement of Uzbekistan, with strongholds in the AfghanistanPakistan border region.

Much ink has been spilt over the AQ-IS rivalry. Assessments range from the overly optimistic scenario of the imminent demise of jihadism as a result of this civil war to the pessimistic view that this rivalry not only demonstrates the new vitality of contemporary jihadism, but also encourages the rivals to constantly improve their lethality in order to win new supporters. ${ }^{41}$ So far, the ISIS challenge has not seriously shattered al-Qaeda's regional alliances. In fact, the most important regional branches have not defected to ISIS; al-Qaeda has even managed to form new regional branch organizations since $2011 .^{42}$ Only groups with a loose affiliation to al-Qaeda have joined ISIS (the Islamic Movement of Uzbekistan, the Caucasus Emirate and Boko Haram) as well as many of the smaller post-2011 jihadi newcomers. The Afghan Taliban movement, one of al-Qaeda's most important allies since the late $1990 \mathrm{~s},{ }^{43}$ has not joined ISIS, choosing instead to launch a vicious fight to root out the ISIS presence in Afghanistan. While ISIS makes much out of the "Caliphate," its proto-state in Syria and Iraq, it is worth remembering that al-Qaeda, through its branches in the Arab world, has also set up and administered a number of proto-states in the post-2011 period, most evidently in Yemen and northern Mali. (In this regard, the accepted notion that "Al Qaeda has never shown much interest in taking or holding territory in order to set up an Islamic state and govern" does not hold up to scrutiny. ${ }^{44}$ ) Similarly, ISIS has managed to form only one new territorial proto-state outside Syria, limited mostly to city enclaves in Libya with much smaller populations and revenue bases compared to its mother organization. ${ }^{45}$

\section{A Hegemonic Rebel Ideology}

The near-term demise of jihadism as a rebel ideology or of al-Qaeda as an organization is clearly unfounded. What the ongoing ISIS-AQ rivalry does suggest, however, is that jihadism now enjoys an unrivaled position as the most popular ideology among armed rebels in the Middle East today. This hegemonic position extends to many Muslim-majority countries. Never in the recent past have so many local rebel and militant groups in such countries sought to latch onto the jihadi logo and brand name with the presumed aim of winning external support or gaining advantages over local competitors. The development is somewhat similar to the rivalry between Marxism and Maoism among Third World rebel groups from the 1960s until the end of the Cold War. A major difference stands out, however. While Marxist rebels could count on material and ideological support from the Communist 
bloc, contemporary jihadism does not have dedicated state sponsors. They have to rely on shadowy private support networks. Such sponsorship has become much more effective today than in the past due to the combined effect of Internet connectivity, migration and the growth of Muslim diaspora communities in high-income countries. ${ }^{46}$

\section{Enter the Youth}

Yet another striking feature of contemporary jihadism that may help us understand the driving factors behind this transnational insurgency is its continued appeal among diverse audiences in the Arab world, especially the youth, despite its deployment of increasingly brutal violence. ${ }^{47}$ Jihadi recruits span the entire spectrum, from well-educated middle-class youth to disenfranchised poor and born-again Muslims with a past history of street crime. Literature on "Muslim radicalization" is highly ambiguous regarding causes, usually offering a long menu of possible drivers, from political repression and feelings of humiliation to poverty and lack of education and job opportunities. Although a full discussion is outside the scope of this study, an often overlooked aspect of contemporary jihadism in the Arab world is its anti-patriarchal and anti-tribal character. This may seem an odd argument, in light of the overwhelming evidence of misogynist discourse and practice by male jihadists. However, patriarchy and tribalism may also be understood as the domination by older men of younger ones, usually through some kind of kinship organization or clientelist network. Jihadi insurgent groups are remarkably anti-patriarchal, which sets them apart from the dominant political structures in the Middle East. ${ }^{48}$ The jihadis not only talk, but also practice a sort of anti-patriarchalism, allowing young people (predominantly men) to gain positions of power and authority in their organizations. This is evident from the large number of jihadi propaganda videos shot in ISIS- and al-Qaeda-ruled proto-states, areas where the jihadis are able to put their ideology into practice. Offices and bureaucracies in territories ruled by jihadi rebels are often run by men in their early twenties. ${ }^{49}$

\section{CONCLUSION}

This article has examined the evolution of jihadism after the Arab uprisings in 2011 and discussed the causes for its remarkable regional expansion since 2001, particularly in the post-Arab Spring period. One cannot avoid the conclusion that jihadism does have a critical popular support base in many Middle East countries, enabling it to operate far more freely than would have been possible had it simply consisted of isolated terrorist cells. The striking resilience of contemporary jihadism is in no small measure a result of its transnational character and the social embeddedness of its local insurgent groups, enabling it to melt away in the face of superior military force and regroup with renewed strength at a time and place of its own choosing.

The common conceptualization of jihadism as a terrorist underground without a significant popular support base is a dangerous misconception that belies today's reality. Instead, it represents a global rebel movement with several territorial proto-states, a huge popular base of geographically scattered and dedicated supporters around the globe and a massive capacity to rally foreign fighters and resources to new conflict areas. This movement cannot be defeated by coercive means alone. In fact, the post-2001 record of the U.S.-led Global War on Terror has, by and large, demonstrated the counterproductive effect of massive reliance of military repression and state coercion. Military action has sapped public support for counterterrorism efforts and undone soft power campaigns to stem recruitment and 
support for jihadi groups. Only when jihadism is conceptualized anew based on a willingness to accept that it represents a political insurgency brought forth by real-world grievances can a sound strategy for stemming its continued expansion be constructed.

${ }^{2}$ The author wishes to thank Dag H. Tuastad, Joakim Parslow, Erling Lorentzen Sogge and Petter
Nesser for valuable comments and feedback on earlier drafts of this publication.
${ }^{3}$ Tom Giratikanon et al.,"How Many People Have Been Killed in ISIS Attacks Around the World,"
New York Times, June 162016 , http://www.nytimes.com/interactive/2016/03/25/world/ map-isis-
attacks-around-the-world.html.
${ }^{4}$ For an illustrative example of the counter-productive effects of the U.S.-led campaign against the
jihadi movement, see Hassan Hassan, "Washington's War on the Islamic State Is Only Making It
Stronger," Foreign Policy, June 162016 , http://foreignpolicy.com/2016/06/16/washingtons-war-on-
the-islamic-state-is-only-making-it-stronger-syria-iraq-libya/.
${ }^{5}$ See Omar Ashour, The De-Radicalization of Jihadists. Transforming Armed Islamist Movements
(Routledge, 2009); and Hamed El-Said and Jane Harrigan, Deradicalising Violent Extremists:
Counter-Radicalisation and Deradicalisation Programmes and Their Impact in Muslim Majority States. (Routledge, 2013).

${ }^{6}$ See the discussion of the contradictions between the typical "kinetic" counterterrorism means employed by the CIA's drone programs and the U.S. State Department's "more soft power counterterrorism measures, which now seek to promote legitimate governance and capacity building to address the somewhat unclear underlying causes of terrorism" in Jason Rineheart, "Counterterrorism and Counterinsurgency," Perspectives on Terrorism 4, no. 5 (2010), http://www.terrorismanalyst s.com/pt/index.php/pot/article/view/122/html; and "The Role of Diplomacy and Soft Power in Combatting Terrorism," NATO Center of Excellence, Defence against Terrorism (COE-DAT) workshop, http://www.coedat.nato.int/publication/workshop_reports/04Diplomacy_Soft_Power_Report.pdf.; and for a study on the variation between soft and hard power of U.S. counterterrorism policies, see Layla Saleh, "Soft Power, NGOs, and the U.S. War on Terror," (PhD dissertation, University of Wisconsin-Milwaukee, 2012): http://dc.uwm.edu/cgi/viewconten t.cgi? article $=1069 \&$ context $=$ etd.

7 "Top Secret America': A look at the Military's Joint Special Operations Command," Washington Post, September 2 2011, https://www.washingtonpost.com/world/national-security/top-secret-americaa-look-at-the-militarys-joint-special-operations-command/2011/08/30/gIQAvYuAxJ_story.html.

${ }^{8}$ See "The Arab War on Terror," Foreign Policy, September 22, 2014, http://foreignpolicy.com/2014/ 09/22/the-arab-war-on-terror/; and "The Rise of the Arab 'War on Terror' Discourse," Muftah.com, November 1, 2013, http://muftah.org/the-rise-of-the-arab-war-on-terror-discourse/\#.V64nXPmLRaQ.

${ }^{9}$ In 2003-2005, a majority or near majority of respondents expressed "high" or "some" confidence in Osama bin Laden in several Middle East countries. See "Islamic Extremism: Common Concern for Muslim and Western Publics," Pew Research Center, July 14, 2005, http://www.pewglobal.org/2005/07/14/islamic-extremism-common-concern-for-muslim-and-westernpublics/.

${ }^{10}$ Mao Zedong wrote in his treatise of guerrilla warfare: "Many people think it impossible for guerrillas to exist for long in the enemy's rear. Such a belief reveals lack of comprehension of the relationship that should exist between the people and the troops. The former may be likened to water, the latter to the fish who inhabit it. How may it be said that these two cannot exist together? It is only undisciplined troops who make the people their enemies and who, like the fish out of its native element cannot live." See Mao Zedong, On Guerrilla Warfare, Chapter 6, https://www.marxists.org/reference/archive/mao/works/1937/guerrilla-warfare/ch06.htm.

${ }^{11}$ One indicator of the relatively broad popular support for jihadists in the region is the openness by which jihadi facilitators are operating in Jordan, a staunchly pro-Western monarchy, from which some 2,500 foreign fighters reportedly have been recruited. See "Jordan Struggles with Islamic Extremism at Home," Wall Street Journal, August 14 2016, http://www.wsj.com/articles/jordan-struggles-withislamic-extremism-at-home-1471225840.

${ }^{12}$ The first AQAP (an acronym for "al-Qaida on the Arab Peninsula," sometimes abbreviated QAP) was a Saudi-based jihadi group, consisting of mostly Saudi Afghan veterans who fought a protracted violent campaign against the Saudi kingdom between 2003 and 2006. The second AQAP denotes a 
Yemen-based group formed in January 2009. AQI stands for "Al-Qaeda in Iraq", and AQIM is "alQaeda in the Islamic Maghrib."

${ }^{13}$ Brynjar Lia, "The Islamist Uprising in Syria, 1976-82: The History and Legacy of a Failed Revolt," British Journal of Middle Eastern Studies, February 9, 2016, http://dx.doi.org/10.1080/1353 0194.2016.1139442.

${ }^{14}$ Craig J. Jenkins et al., "Seedbeds of Insurgency: Structure and Dynamics in the Egyptian Islamist Insurgency, 1986-99," Journal of Peace Research 51, no. 4 (2014): 470-86.

${ }^{15}$ See, for example, Mohammed M. Hafez, "Armed Islamist Movements and Political Violence in Algeria," Middle East Journal 54, no. 4 (2000): 572-91; and Luis Martinez, The Algerian Civil War 1990-1998 (Columbia University Press, 2000).

${ }^{16}$ Fawaz Gerges, "The Decline of Revolutionary Islam in Algeria and Egypt," Survival 41, no. 1 (1999): 113-25.

${ }^{17}$ For an authoritative account on the establishment and evolution of al-Qaida in Iraq, see Truls Hallberg Tønnessen, "Al-Qaida in Iraq: The Rise, The Fall and the Comeback" (PhD dissertation, University of Oslo, 2015).

${ }^{18}$ In North Africa, the Groupe Salafiste de la Predication et la Combat (GSPC) formed in 1998, was an offshoot group of the largest jihadi rebel group in Algeria in the 1990s, the Groupe Islamique Armée (GIA). The latter had mostly disappeared from the scene by the early 2000s. In 2006-7, the GSPC sought and obtained recognition as al-Qaida's regional branch organization. In Yemen, a series of Islamist militant groups had operated in the country since the early 1990s. In January 2009, the remnants of the Saudi QAP merged formally with Yemeni jihadi factions and formed the AQAP. The Shabaab, also known as the Islamic Youth Movement, was formed in the mid-2000s, operating first as a kind of military arm of the Islamic Court Union in Somalia until the Ethiopian invasion in late 2006. It grew steadily closer to al-Qaida towards the end of the 2000s and became formally its official branch on the Horn of Africa in early 2012.

${ }^{19}$ The emphasis on political reforms was most pronounced in Morocco where the King appointed for the first time a prime minister from the Islamist opposition party, PJD as head of a coalition government.

${ }^{20}$ See, for example, data presented in Ryan Pereira, "Radical Change: The Impact of Islamic State on Tunisia," Terrorism Monitor 14, no. $10 \quad$ (May $16 \quad$ 2016), http://www.jamestown.org/uploads/media/Terrorism_M onitor_Volume_XIV_Issue_01.pdf.

${ }^{21}$ See, for example, Mokhtar Awad and Mostafa Hashem, "Egypt's Escalating Islamist Insurgency," Carnegie Middle East Center, October 21, 2015, http://carnegie-mec.org/2015/10/21/egypt-sescalating-islamist-insurgency/ijgn.

${ }^{22}$ There have been relatively few terrorist attacks in Jordan, but several serious ISIS-linked plots. See, for example, Tim Hume, "6 Jordanian Security Forces Killed in Car Bomb Attack on Syrian border," CNN, June 21, 2016, http://edition.cnn.com/2016/06/21/middleeast/jordan-car-bomb-attack/; Suleiman Al-Khalidi, "Jordan Says Foils Islamic State Plot to Attack Civilian, Military Targets," Reuters, March 2, 2016, http://www.reuters.com/article/us-mideast-crisis-jordan-militantsidUSKCN0W40QA; and Joby Warrick and Taylor Luck, "Jordan Disrupts Major Al-Qaeda Terrorist Plot," Washington Post, October 21, 2012, https://www.washingtonpost.com/world/nationalsecurity/jordan-disrupts-major-al-qaeda-terrorist-plot/2012/10/21/e26354b4-1ba7-11e2-9cd5b55c38388962_story.html.

${ }^{23}$ See, for example, Christine Petré, "Tunisian Salafism: The Rise and Fall of Ansar al-Sharia," FRIDE Policy Brief, no.209 (October 2015), http://fride.org/descarga/PB209_Tunisian_Salafism.pdf; and Aaron Zelin, "Meeting Tunisia's Ansar al-Sharia," Foreign Policy, March 8, 2013, http://foreignpolicy.com/2 013/03/08/meeting-tunisias-ansar-al-sharia/.

${ }^{24}$ See, for example, Omar Ashour, "Lions Tamed? An Inquiry into the Causes of De-Radicalization of Armed Islamist Movements: The Case of the Egyptian Islamic Group," Middle East Journal 61, no. 4 (2007): 596-625; Omar Ashour, "Deradicalisation Revisited," Washington Post, February 18, 2015, https://www.washingtonpost.com/blogs/monkey-cage/wp/2015/02/18/deradicalization-revisited/; and Hamed El-Said and Jane Harrigan, Deradicalizing Violent Extremists: Counter-Radicalisation and Deradicalisation Programmes and Their Impact in Muslim Majority States (Routledge, 2013).

${ }^{25}$ The concept is discussed in Alexander V. Simmons, Socially Embedded Insurgencies (Naval Postgraduate School, 2009), http://www.dtic.mil/dtic/tr/fulltext/u2/a514335.pdf. 
${ }^{26}$ Al-Qaeda's current leader, Ayman al-Zawahiri, discussed this at length in his 2001 treatise, "Chapter 11," Knights Under the Prophet's Banner. For an English translation, see https://azelin.files.wordpress.com/2010/11/6759609-knights-under-the-prophet-banner.pdf.

${ }^{27}$ Brynjar Lia, "Understanding Jihadi Proto-States," Perspectives on Terrorism: Special Issue on the Islamic State 9, no. 4 (2015): 31-41, http://www.terrorismanalysts.com/pt/index.php/pot/article/vie $\mathrm{w} / 441 / \mathrm{html}$.

${ }^{28}$ One example of how the current anti-ISIS campaign may be counterproductive and drive Sunni Arab population back into the hands of ISIS is the recent reporting of the large-scale atrocities and abuses committed by Iraqi Shiite militias during the liberation of the ISIS-held town of Falluja in Iraq. See "Special Report: Massacre Reports Show U.S. Inability to Curb Iraq Militias," Reuters, August 23, 2016, http://www.reuters.com/article/us-iraq-massacres-falluja-special-report-idUSKCN10Y1VD.

29 “Thousands Enter Syria to Join ISIS despite Global Efforts," New York Times, September 26, 2015.

${ }^{30}$ In addition, during the Cold War, the United States gave very high priority to keeping the Soviet Union out of the Middle East.

${ }^{31}$ See, for example, John Hannah, "Saudi Arabia Strikes Back," Foreign Policy, June 16, 2016, http://foreignpolicy.com/2016/08/16/saudi-arabia-strikes-back-3/.

${ }^{32} \mathrm{See}$, for example, the warnings to the Obama administration in this Brookings policy brief: Tamara Cofman Wittes and Daniel L Byman, "Muslim Brotherhood Radicalizes," Brookings Institution, January 2014, https://www.brookings.edu/research/muslim-brotherhood-radicalizes/.

${ }^{33}$ Recruits have reportedly come from disgruntled revolutionary Salafists (the Hazemun movement), disaffected Muslim Brotherhood youth and other groups. See "What's Next for Egypt's IS Affiliate after Killing of Leader?" Al-Monitor, August 14, 2016, http://www.almonitor.com/pulse/origin als/2016/08/egypt-killing-leader-isis-affiliate-ansar-bayt-maqdis.html; and "Push for Retribution in Egypt Frays Muslim Brotherhood," New York Times, August 5, 2015.

${ }^{34}$ See, for example, "Egypt's Rising Security Threat," The Tahrir Institute for Middle East Policy, 2015, http://timep.org/wp-content/uploads/2015/11/Tahrir_Report_FINAL_WEB.pdf.

${ }^{35}$ Under Osama bin Laden's leadership, al-Qaeda was wary of bestowing its brand name on several local groups seeking bin Laden's approval, fearing that their disunity and lack of dedication to the global jihadi cause would harm al-Qaida's cause. See "Letters from Abbottabad: Bin Laden Sidelined?' CTC Report, May 3, 2012, https://www.ctc.usma.edu/posts/letters-from-abbottabad-bin-ladinsidelined.

${ }^{36}$ For the shift from jihadi web forums to social media platforms, see Aaron Zelin, "The State of Global Jihad Online," New America Foundation Report, February 4, 2013, https://www.newamerica.org/international-security/policy-papers/the-state-of-global-jihad-online/; and Cole Bunzel, "Are the Jihadi Forums Flagging? An Ideologue's Lament," Jihadica.com, March 20, 2013, http://www.jihadica.com/are-the-jihadi-forums-flagging-an-ideologue\%E2\%80\%99s-lament/.

${ }^{37}$ The United States offered direct support to the Ethiopian occupation of Somalia between late 2006 and 2009 by inter alia providing military aid, financial support, and diplomatic backing. See, for example, "U.S. Support Key to Ethiopia's Invasion," USAToday, January 7, 2007, http://usatoday30.usatoday.com/news/world/ 2007-01-07-ethiopia_x.htm; and Abdi Ismail Samatar, "Ethiopian Invasion of Somalia, U.S. Warlordism \& AU Shame," Review of African Political Economy 34, no. 111 (2007): 155-65.

${ }^{38}$ The fact that Arabic is the dominant, but not exclusive, language used in these web fora may explain the low prioritization of the Taliban struggle. Furthermore, the Taliban organization maintains its own websites and online propaganda channels in multiple languages.

${ }^{39}$ This assessment hence departs from that of Martha Crenshaw in her recent analysis: "There Is No Global Jihadist Movement," The Atlantic, March 11, 2015, http://www.theatlantic.com/international/a rchive/2015/03/there-is-no-global-jihadist-movement/387502/.

${ }^{40}$ In late July 2016, JaN renamed itself Jabhat Fath al-Sham (The Conquest of the Levant Front), apparently signaling a split by declaring "no affiliation to any external entity." In reality, however, alQaeda seems to have endorsed JaN's renaming process. Their ties appear to remain strong with Jawlani heaping praise on Zawahiri and his deputy for their "blessed leadership." See "Syrian Nusra Front Announces Split from al-Qaeda," BBC, July 29, 2016, http://www.bbc.com/news/world-middleeast-36916606; and "Analysis: Al Nusrah Front Rebrands Itself as Jabhat Fath Al Sham," Long War 
Journal, July 28, 2016. http://www.longwarjournal.org/archi ves/2016/07/analysis-al-nusrah-frontrebrands-itself-as-jabhat-fath-al-sham.php.

${ }^{41}$ This assessment is borne out of observations from several regions. For example, with regard to AQIM in West Africa, one expert assesses that "[t]he increasing frequency of AQIM attacks and their timing, which has often coincided with IS assaults, suggests the group is trying to ensure it is not outdone by the more radical agenda of IS. The Bamako attack, for example, came just 10 days after the IS Paris attacks in November 2015; and the Ouagadougou attack occurred almost immediately after IS carried out an attack in Jakarta, the group's first assault in Southeast Asia." Cited in Jessica Moody, "Foreign Assets under Threat: Is AQIM Preparing an In Amenas-Style Attack?" Terrorism Monitor 14, no. 14 (2016): 7-10, http://www.jamestown.org/uploads/media/TM__Vol_14_Issue_03.pdf.

${ }^{42}$ They include the Nusra Front (now renamed as "The Conquest of the Levant Front") and al-Qaida on the Indian Subcontinent (AQIS), the latter formed in 2014.

${ }^{43}$ The al-Qaida-Taliban relationship was fraught with many contradictions and tensions. See Anne Stenersen, Brothers in Jihad: Explaining the Relationship between al-Qaida and the Taliban, 19962001 (University of Oslo, Ph.D. dissertation, 2012); and Alex Strick van Linschoten and Felix Kuehn, An Enemy We Created: The Myth of the Taliban/Al-Qaeda Merger in Afghanistan, 1970-2010 (Hurst, 2012).

${ }^{44}$ Cited in Daniel Byman and Jennifer Williams, "ISIS vs. Al Qaeda: Jihadism's Global Civil War," National Interest, February 24, 2015, http://nationalinterest.org/feature/isis-vs-al-qaedajihadis m\%E2\%80\%99s-global-civil-war-12304.

${ }^{45}$ The proto-state in northern Nigeria (see Table 1) was set up by Boko Haram with minimal ISIS involvement.

${ }^{46}$ Brynjar Lia, Globalization and the Future of Terrorism (Routledge, 2005): 94-5, 116-20; and Nicola McGarrity, "The Criminalisation of Terrorist Financing in Australia," Monash University Law Review 38, no. 3 (2012): 57.

${ }^{47}$ Al-Qaida's global appeal is discussed in Brynjar Lia, "Al-Qaida's Appeal: Understanding Its Unique Selling Points," Perspectives on Terrorism 2, no. 8 (2008): 3-10, http://www.terrorismanalysts.com/pt/index.php/pot/article/view/44/html.

${ }^{48}$ Brynjar Lia, "The Jihadi Movement and Rebel Governance: A Reassertion of a Patriarchal Order?" Die Welt des Islams, Special Issue on Patriarchy and the Arab Spring: Liberation or Backlash? (forthcoming).

${ }^{49}$ As seen in the following videos: "To Establish the Religion - Wilāyat Țarābulus," March 30, 2016, http://jihadology.net/2016/03/30/new-video-message-from-the-islamic-state-to-establish-the-religionwilayat-\%E1\%B9\%ADarabulus/; and "And What Is to Come Will Be More Devastating and Bitter Wilāyat Țarābulus," March 26, 2016, http://jihadology.net/2016/03/26/new-video-message-from-theislamic-state-and-what-is-to-come-will-be-more-devastating-and-bitter-wilayat-

$\%$ E1\%B9\%ADarabulus 